\title{
The German Waterpenny case : a paradigm for the emerging common law of Europe
}

Citation for published version (APA):

Backhaus, J. G. (1997). The German Waterpenny case : a paradigm for the emerging common law of Europe. METEOR, Maastricht University School of Business and Economics. METEOR Research Memorandum No. 022 https://doi.org/10.26481/umamet.1997022

Document status and date:

Published: 01/01/1997

DOI:

10.26481/umamet.1997022

Document Version:

Publisher's PDF, also known as Version of record

\section{Please check the document version of this publication:}

- A submitted manuscript is the version of the article upon submission and before peer-review. There can be important differences between the submitted version and the official published version of record.

People interested in the research are advised to contact the author for the final version of the publication, or visit the DOI to the publisher's website.

- The final author version and the galley proof are versions of the publication after peer review.

- The final published version features the final layout of the paper including the volume, issue and page numbers.

Link to publication

\footnotetext{
General rights rights.

- You may freely distribute the URL identifying the publication in the public portal. please follow below link for the End User Agreement:

www.umlib.nl/taverne-license

Take down policy

If you believe that this document breaches copyright please contact us at:

repository@maastrichtuniversity.nl

providing details and we will investigate your claim.
}

Copyright and moral rights for the publications made accessible in the public portal are retained by the authors and/or other copyright owners and it is a condition of accessing publications that users recognise and abide by the legal requirements associated with these

- Users may download and print one copy of any publication from the public portal for the purpose of private study or research.

- You may not further distribute the material or use it for any profit-making activity or commercial gain

If the publication is distributed under the terms of Article $25 \mathrm{fa}$ of the Dutch Copyright Act, indicated by the "Taverne" license above, 


\section{The German Waterpenny Case: A Paradigm for the Emerging Common Law of Europe}

Prof. Dr. Jürgen G. Backhaus

Maastricht University, AE

P.O. Box 616

6200 MD Maastricht

The Netherlands

tel: $+31-43-3883652 / 3636$

fax: $+31-43-3258440$

email: f.schijlen@algec.unimaas.nl 


\begin{abstract}
Europe is an area with many different jurisdictions. The attempts of the harmonizations of law have focussed on legislated law, but less on the free movement of legal professionals and on understanding of how law is being made in the different contituting parts of the European Union. In this context, it has been suggested to follow the American example and use economic analysis as a unifying bracket. In particular, law and economics as a subdiscipline of economics (J.E.L. code K) may provide such a unifying ingredient. The more European lawyers, atterneys, barristers, procecuters and judges as well as the rule drafting civil servants think in terms of law and economics concepts, the easier it will be for them to settle their conflicts, as sharp as those may be in particular cases.

The German waterpenny case, which not only vindicates the Coase theorem as a conceivable tenet of legislation, but also deals with a problem recurring in every one of the Member States of the European Union, provides a good example for showing how this theory driven process of harmonization of European law could take place without infringing on the sovereignty of any one Member State.
\end{abstract}

J.E.L. code: K00

Key words: Coase theorem, court decisions under uncertainty 


\section{The German Waterpenny Case: A Paradigm for the Emerging Common Law of Europe}

Sometimes, arcane cases come before high courts and require a specific ruling. The German waterpenny case ${ }^{1}$ is such an instance. At stake was not just the issue of who ultimately would have to bear the costs of using artificial fertilizer that may contaminate ground water. Rather, in settling this issue the court faced a decision space of uncertainty and had to settle a basic issue on which, in the future, an entire system of rulings settling liability claims would have to rely. The decision space was one of uncertainty and not risk $^{2}$ because neither the set of conceivable outcomes nor the attributable probabilities can be known beforehand. Moreso. Even the legal system in which the ruling ultimately would serve as a precedent can no longer be known, as the German constitutional court just as other highest courts within the European Union now operates in the context of European harmonization efforts that link the different legal systems of European Member States - as well as those aspiring to become members - one to another. There is substantial pressure to allow for a convergence of these legal systems, when by architecture and in-built procedures they operate according to different rythms. Ultimately, common features and traits will become apparant, and these will be principles that may not have guided any single decisions of courts or other rule makers, but they may be able to further understanding of the decisions and rules as if they had guided them.

Europe is an area with many different jurisdictions. The attempts of the harmonizations of law have focussed on legislated law, but less on the free movement of legal professionals and even

\footnotetext{
1 BundesVerfassungsGerichts Entscheidung, Gen. 413/88 and 1300/93.

2 See Frank Knight, Risk, Uncertainty and Profit. Chicago: University of Chicago Press 1971 (Boston: Houghton Mifflin, 1921)
} 
less on understanding how law is being made in the different contituting parts of the European Union. In this context, it has been suggested ${ }^{3}$ to follow the American example and use economic analysis as a unifying bracket. In particular, law and economics as a subdiscipline of economics (J.E.L. code K) may provide such a unifying ingredient. The more European lawyers, atterneys, barristers, procecuters and judges as well as the rule drafting civil servants think in terms of law and economics concepts, the easier it will be for them to settle their differences, as sharp as those may be in particular cases.

The German waterpenny case, which not only vindicates the Coase theorem as a conceivable tenet of legislation, but also deals with a problem recurring in every one of the Member States of the European Union, provides a good example for showing how this theory driven process of harmonization of European law could take place without infringing on the sovereignty of any one Member State.

The paper is a contribution to the literature which looks at the development of law from the point of view of economic efficiency. There is a large number of studies showing that the (American) common law moves towards economically efficient solutions. Some authors in the United States, especially those belonging to the Chicago School, use the wealth maximization hypothesis not only for the reconstruction and interpretation of past decisions, but also as guidelines in adjudication. In Europe, scholars have been more reluctant and preferred to confine the use of the wealth maximization hypothesis strictly to the interpretation of legislated and case law. However, the Waterpenny Case, which is only one in a string of related cases

See Hein Kötz, "A Common Private Law for Europe". In: Bruno de Witte, Caroline Forder (eds.), The Common Law of Europe. Deventer: Kluwer, 1992, pp. 31-42. 
decided by the German constitutional court, clearly shows that the court is willing to assign economic analysis a larger role also in adjudication perhaps even despite itself. This can have important implications for the development of a co-herent European law emanating from the legislation and adjudication of the different Member States.

In this essay, I first give a brief sketch of the Coase theorem as it relates to law and economics analysis in the context of European legal harmonization. Secondly, the specific case, the German waterpenny case, is reviewed in detail. The third section covers implications of this case for future legislation and adjudication.

I.

The basic problem underlying the Waterpenny Case is readily stated. Consider farmers who use artificial fertilizer to enhance the yield of their crop. Some of the fertilizers, not intentionally but unavoidably, will enter the ground water, a common resource. The water that is pumped into households and industry, including farms, needs to be prepared according to specifications. If alien substances occur in the water, they have to be cleansed. Hence, the more fertilizer is being used on the farms, the more cleansing the water works have to do, and typically the higher the cost of water preparation is. In this event, we encounter a typical problem of externalities and should therefore consider the Coase theorem.

If the costs of transactions can be ignored, the original assignment of property rights will not 
affect the ultimate allocation of resources, it will however affect the distribution of wealth. ${ }^{4}$ In the case at hand, if transactions costs can be left out of the equation, it should not matter for the ultimate use of resources, that is the use of fertilizer, land and implicitly water, who has the right to the water, the farmer or the water works, the farmer who inadvertantly but unavoidably pollutes the water or the water authorities who have to cleanse the water in order to make it fit for consumption. The assumption of negligable transactions costs is reasonable in this case. Transactions costs involve the costs of gathering information, arriving at contractual agreements and seeing to it that these agreements are lived by. The parties involved, the farmers and the water works, are well organized and the political process is fit to provide rules and frameworks that can serve to regulate the use of land and water, all in terms of current established procedures. Although invariably haggling is going to occur, the marginal political cost of arriving at a water regulation can be assumed to be quite negligable, at least in comparison to the issues at stake. Hence, the Coase theorem informs us that it should be immaterial whether the farmers have the right to use fertilizer on their ground at their discretion, even at the risk of spoiling the ground water, or the water authorities have the right to uneffected ground water to be conveyed to their customers.

Of course, as mentioned before, "immaterial" does not mean politically irrelevant, as distributional issues - not covered by the Coase theorem - may loom large.

4 See Ronald H. Coase, The Problem of Social Cost, Journal of Law and Economics, 3, 1960, pp. 1 sequ. 


\section{II.}

When the waterpenny decision was published, there was an outburst of popular discontent with the constitutional court. ${ }^{5}$ The farmers were said to be dumping their "poison" on the fields, and now they were being bribed to impose less harm on the natural resource on water. In the cloak of the market economy, this political instrument appeared, in violation of the "polluter pays principle”, "a late victory of Lothar Späth, but defeat of reason". ${ }^{6}$ In the face of such steamy rethoric, it is probably worth considering the case itself. The case had been brought by water authorities in Baden Württemberg and Hesse against the states of Baden Württemberg and Hesse (seperately) claiming violation of the Federal constition. For extracting ground water, water authorities in Baden Württemberg had been charged between one and ten pfennigs per cubic meter, in Hesse between ten and fifty pfennigs, ultimately one Mark per cubic meter. The total revenue from these levies amounted to between 145 and 165 million German Marks per year in Baden Württemberg and between 25 million German Marks and ultimately 160 million German Marks in Hesse. The authorities claimed violation of articles 2.1 Basic Law (general guarantee of freedom and personal integrity), 3.1 (equality), 12.1 (freedom of choice of profession and line of business), 14.1 (guarantee of private property as well procedural violations). Violation of article 12 had been claimed only by the paper industry, which had joined the

5 See for instance, the coverage of different editorials in Frankfurter Allgemeine Zeitung, 17 February 1996, Nr. 41, p. 2. Rarely has the constitutional court been so harshly criticized in the popular press, with only one recent instance rivaling the waterpenny commotion as when the court ruled on the seperation of church and state.

6 Lothar Späth had been the Prime Minister of the state of Baden Württemberg where the water penny was initiated at the behest of economists from the University of Constance. The Prime Minister had later resigned over a travel funding dispute and started a new carreer as a promotor of industrial development in the new federal state of Thuringia. 
suit.

A definitional issue blurs a clear cut analysis of the case. Under German law, there is a difference between fees charged for specific services rendered by a public institution, special charges levied for specific purposes, taxes and prices. Roughly speaking, fees require specific services rendered and in general have to mirror in value the benefit provided or the costs of the provision. The revenues from charges have to be committed to the specific purpose for which they are levied, they have to be earmarked. Taxes are levied for the general fund with no specific offsetting benefit granted, while prices are subject to the forces of supply and demand. Under this terminology, the states could not levy a tax for lack of competence, the water charges could not qualify as fees nor prices, nor could they qualify as special charges because the beneficiaries were not identical to the stated purpose. Most of the argument revolves around these definitial issues, through which the court cut by stating, that the traditional notions and definitions were irrelevant and only the function of the policy instrument had to be considered in the light of their guarantees and protections provided by the fiscal constitution. ${ }^{7}$ Secondly, the court decided that water as a natural resource was a common property, using it created a specific advantage which could be taxed away (Abschöpfen) either in part or as a whole.

On several occasions, the court explicitly cites "economists" and "economics" and even uses economic jargon, such as "externalities", "market failure" and functional instruments to "internalize" external costs. It cites incentive effects of the water penny and legislative discretion between different functional instruments. Finally, the court emphasizes the care that the

\footnotetext{
$7 \quad$ Statement (Leitsatzt) 1.
} 
legislatures have taken in preparing the legislation in Baden Württemberg and Hesse relying on experts in environmental economics and environmental law and the overwhelming consensus of these experts in drafting their respective legislation.

The emphasis of the court on economic notions, on the functions of particular instruments and on legislative due care each need a word of explanation.

\section{Externalities and Market Failure}

With this decision, the constitutional court in Karlsruhe has juxtaposed the economic principles of neo-classical public finance onto the received doctrine that served to classify public revenues. By buying into modern public finance, which is a dogmatic system by itself, the court has substituted an old dogmatic system, the old classificatory doctrine of public revenues that had strong public law underpinings, by the modern theory of public finance as it has emerged consequent to the development of the theory of market failure. ${ }^{8}$ From the point of view of constitutional legal doctrine, this juxtaposition did not require any particular change in methods. One economic system can serve just as well as the other, just as long as there is a linkage that can translate the economic notions into legal ones. That linkage is provided by the theory of functions the court has been using for some two decades now in the most diverse sub-areas of constitutional litigation.

\section{The Theory of Functions}

8 See Francis Bator, “The Anatomy of Market Failure", Quarterly Journal of Economics, 72, 1958, pp. 351-379. 
For many years now, the court has developed the theory of functions (of legal institutions or legal arrangements) that serves as an entry port of almost any kind of a scientific argument into its jurisdiction, much as the Brandeis brief does in the United States. ${ }^{9}$ The court has had ample opportunity to test this theory, since the German constitution has been broadly conceived and can be interpreted and tested as serving to protect many specific institutions. For instance, such institutions as capital markets, labour markets, collective bargaining and its equilibrating forces, private property, vested rights of university scholars in their traditional forms of research, corporate forms such as joint stock companies, limited liability companies, limited liability companies on shares etc., to name just a few are all protected under the constitution in their basic viability. The doctrine of viability which serves as the standard test that the court uses in order to judge the constitutionality of particular act of parliament requires that the basic function of the institution in question not be impaired. A rule passes muster before the constitution if the institution in question, such as a corporation under the co-determination act, to name just one example, is still viable after application and implementation of the act under review. In order to determine whether an institution is viable under changed conditions, one has to first determine what constitutes its viability, i.e. in the notions of the court what is its function. If, for instance, the function of corporation is held to be that capital owners have a chance to invest and earn a return on their capital that reflects both the scarcity of capital and their business acumen, and to give workers a chance to be employed in a particular community, then these three functions must be possible to be discharged even after any rule has been imposed and without major impediments in the sense that such impediments cannot be overco-

9 See Peter Senn, "Science as a Source of the Law", in Jürgen Backhaus The Elgar Companion to Law and Economics, Aldershot: Elgar, 1998. (Prior to publication available from both the author and the editor). 
me by the kind of management that can be expected to run such a corporation. Likewise, and to move the discussion closer to the case at hand, a specific public revenue source may be said to have the function to fulfill the revenue needs of a specific public institution that is dedicated to a specific need (Anstalt), and then the doctrine has to serve the purpose of protecting both the institution in terms of its revenue needs and the captive customers of the institution from overcharging. This is the reason for the dogmatic theory of revenue sources that the court cut through for the case at hand. It argued, instead, that a Pigouvian tax (the court did not use that term) is not a revenue seeking instrument of taxation but rather an incentive oriented instrument to seek a particular response on the part of the taxee, and hence it falls outside the received doctrine. Then the purpose must be to show that the function of effecting those incentives in the desired manner can well be accomplished by the instrument used and in the way the instrument is being used. Hence, if the desired purpose is to reduce the reliance on the natural resource of water by reducing water consumption, and if it can be shown that a water charge imposed on the water authorities and passed along to the customers serves that purpose, then this specific fiscal instrument can be considered functional and it therefore passes the constitutional test.

Yet a popular sentiment insists that the water penny flies in the face of the "polluter pays principle" and therefore violates the most basic principle of civil law. Of this, the court had to find an answer in terms of its theory of functions, which it did. Nothing in the theory of Pigouvian taxes implies that the charges levied on those whose behaviour imposes externalities on others have to be benefiting those very inducers of externalities nor need they be used for otherwise containing harm resulting from the externalities. The revenues from the charges, if they occur, can be used for any purpose under Pigouvian doctrine. The point of the Pigouvian 
levy is to correct for an externality, Pigou cuts through the link layed by Wicksell ${ }^{10}$ to always consider public outlays and public revenues in one and only one decision. So the court argues correctly that it is within the discretion of the government to levy the charge, and it is likewise within the discretion of the government to use the resulting revenue according to its policies. Even more so, the court argues that if a program can be designed that uses the revenues so as to further the policies envisaged, nothing in the test of functionality prevents a government from pursuing that course.

It is here where the Coase theorem enters. The "polluter pays principle" does not make the distinction between allocation and distribution in an economy. The agent who "causes" an externality is responsible in the sense of being reliable, that is he is responsible for correcting the allocation of resources as well as the resulting re-distribution of income or wealth. The Coase theorem, instead, makes the standard distinction in economics that separates issues of the allocation of resources from issues of income or wealth. In order to achieve this result for the water penny, that is in order to reject the argument that the consumers who ultimately bear the burden of the water penny, private households, industrial corporations etc. should also somehow benefit from the charge intended to reduce water consumption, the court has to disconnect the allocation part; creating incentives for prudent water use; from the distribution aspect; who benefits from the revenues of the water penny? Since the Coase theorem is the vehicle for this argument, the court invoces the consencus among economists ${ }^{11}$ and through its

10 See Knut Wicksell, Finanztheoretische Untersuchungen, Jena: Gustav Fischer, 1896. Modern public choice theory as in the consequence of Buchanan's work is based on Wicksell's Finanztheoretische Untersuchungen.

11 The assumption by the court is correct. Ronald H. Coase had received the Nobelprize in economics about when the litigation started. 
theory of functions applies the Coase theorem to the water penny case.

By using the theory of functionality as a vehicle to introduce the evidence from social sciences into jurisprudence and notably the jurisdiction of the constitutional court, the court runs the risk of using theoretical results that have not been sufficiently corroborated. The results from social science research are, of course, always subject to the caveat that 1. conditions may change and 2. the evidence may simply have been misleading and what appeared to have been a thorough result, for instance, may rather be the result of spurious correlations. While some courts in the United States have strongly relied on even recent social science research results in ordering strong measures, the bussing decisions on the basis of James Coleman's research may be one particularly conspictuous example, the German constitutional court has been more circumspective in designing a test with a specific consequence. It is here where the notion of legislative due care (Sorgfaltspflicht des Gesetzgebers) comes in.

\section{Legislative Due Care}

Repeatedly, the German constitutional court has offered this reasoning in upholding controversial legislation. The instance has probably been pioneered when the university constitution act was challenged, and it has been perfected when the co-determination act of 1976 was under review. ${ }^{12}$ In such instances, when a specific arrangement due to a rule, an act or the composite result of different rules, acts, rulings etc. result in a specific clearly circumscribed outcome and parties claim to be violated in their basic rights, the functional test as described above of the

12 See Jürgen Backhaus, Mitbestimmung im Unternehmen, Göttingen: Vandenhoeck und Roeprecht, 1987. 
institution in question is being applied. For instance, it could and has been argued that the water penny makes it impossible for the Hessian paper industry to compete fairly in international paper markets, against foreign competition to supply the big printing locations in Frankfurt. Against this has to be weighed the concern for water conservation which can, so the functional argument for the water penny goes, be accomplished by on the one hand discouraging water use by end consumers and on the other hand discouraging water pollution by farmers through fertilizers and conceivably pesticides. Yet, what if farmers cannot be discouraged from polluting ground water, and end consumers cannot be discouraged from using ever increasing amounts of water, with water authorities being rendered unable to make ends meet and fulfill their functions? In that case, the court has consistently argued, the factual evidence on which the decision rested, that has been introduced through the functionality theory, is erroneous; and consequently, the decision maybe (but also may not be) erroneous as well since, ex falso quodlibet! In that case, and if the institution in question can clearly not perform the function attributed to it by the legislation and the court, it is upon the legislature to correct the act of parliament.

This requirement to correct an erroneous act of parliament, to my knowledge is as far as constitutional courts go an invention of the judges in Karlsruhe. It is an interesting fruit of the eternal German Werturteilstreit, the struggle over the meaning of different scholarly methods, and it is the ultimate corrective on the doors swung wide open to introduce social science evidence into jurisdiction. Given in requirement of erroneously based acts of parliament to be subject to review, and given the traditional emphasis on certainty in the law that characterizes every Western legal system, the court designed a doctrine of due legislative care in order to safeguard against sudden reversals of jurisdiction and legislation. In addition to considering the 
constitutionality of a particular arrangement such as an act of parliament, a directive, European legislation involving German persons (legal or personal), lower court rulings or administrative rulings, the constitutional court has designed a two pronged procedure to allow social science evidence into the law. On the one hand, through the theory of functions, most any type of respectable social science result can enter right into the decisions of the court. This is even the case for feminist jurisprudence as long as it is scholarly sound. The current president of the court promotes this course. On the other hand, the court has always insisted, and consistently does so, that legislatures, when introducing social science evidence into their considerations as they should, they also should take due care in not glossing over the evidence and being circumspecting in gathering enough of it. Hence, when in particular far reaching decisions have to be taken and much evidence has been mounted by either side before the parliament and its committees, the court raises the standard of legislative care in requiring extensive hearings prior to the legislation. That is, if any parliament, either one of the sixteen constituant federal states or the federal parliament itself, wish to pass an act of legislation that can be expected to be challenged in front of the constitutional court, that parliament now has to engage in an extensive procedure of fact finding and hearings prior to legislating just in order to make sure that the act under controversy will survive before the constitutional court, of course always under the proviso that the evidence does not overwhelmingly change. Hence, by on the one hand lowering the echelon for admissable evidence and opening the doors for social science research results, the court at the same time has increased the echelon of evidence on the legislatures by forcing them to consider and devulge that same social science evidence beforehand. This may be the wider implication of the functionality theory for German jurisdictions.

Yet, we also need to consider the implications for Europe. 
III.

From a European point of view, the musings of the German constitutional court over the implications of the provisions of the German Basic Law of 1949 may appear to be rather immaterial. What is the law in Kehl may not necessarily be the law across the river Rhine in Strasbourg. Yet, the specific approach taken by the court in interpreting this Basic Law, the main provisions of which can, by the way, also been found in various European treaties, by far exceeds the boundaries of the German territories. First of all, legal doctrine is also a scholarly discipline that is internationally interconnected. The so-called German Rechtskreis also includes Greece and most of the Central European countries under transition. So, nolens wolens German legal doctrine enters the doctrine of other European states as well. These states are members of the Council of Europe, and in that capacity they also influence the process of European legal harmonization. Others are members of the European Union and in that capacity they input into the process of European harmonization in law.

A more important because less obvious element needs to be emphasized. The law in any country deals with the behaviour of people, and the social sciences have only in the last one hundred years taken a meteoric rise, while law as a scholarly discipline is several thousand years old. This scholarly confrontation has been met in different ways by different legal systems, but the American system with the Brandeis brief and the German system with the theory of functionality have been particularly open to social science research. Social science itself is international, and social scientists are competing internationally, subjecting their research to international scrutiny as it appears. Hence, social science research is becoming ever more powerful as an element of the set of data anybody, also a judge, needs to consider. That legal 
doctrine has a lead that finds a way to systematically integrate social science research into jurisdiction without compromising the core of the body of the law. With its pioneering decisions, of which the water penny case is only one, the German constitutional court has shown how this integration can be accomplished without doing damage to the core of the law. In doing this, the court, of course, does not export German jurisprudence in the sense of the specific stipuliations of German legislation, including the Basic Law, into other countries, undergoing the same process of harmonization; what it exports is the specific method that is at variance with, for instance, the French method of jurisprudence that is based more stongly into Latin doctrine and emphasizes specific notions and their interpretations. The dispute over the classification of taxes is a very good point of illustration, as in that area Germany used to follow largely French administrative legal doctrine.

In opening this door to social science, and also providing for the requisite safeguards any high court needs to maintain when admitting uncontrollable streams of evidence, the court necessarily opted for those social sciences that have the strongest evidence to marshal. At the present moment, economics is among these sciences, and law and economics is the discipline through which the results of economic science can be filtered into legal doctrine. Economic science, as any social science, is, of course, international and as such not bound by specific jurisdictions. In this sense, active law and economics research that filters into the decisions of high courts in itself a motor of the harmonization of law to the extent that courts are willing to follow the exemple of the German constitutional court, as it has been demonstrated in the water penny case.

\section{References}


Jürgen Backhaus, Mitbestimmung im Unternehmen, Göttingen: Vandenhoeck und Roeprecht, 1987.

Francis Bator, "The Anatomy of Market Failure”, Quarterly Journal of Economics, 72, 1958, pp. 351-379

Ronald H. Coase, The Problem of Social Cost, Journal of Law and Economics, 3, 1960, pp. 1 sequ.

Frankfurter Allgemeine Zeitung, 17 February 1996, Nr. 41, p. 2.

Frank Knight, Risk, Uncertainty and Profit. Chicago: University of Chicago Press, 1971 (Boston: Houghton Mifflin, 1921).

Hein Kötz, “A Common Private Law for Europe”. In: Bruno de Witte, Caroline Forder (eds.), The Common Law of Europe. Deventer: Kluwer, 1992, pp. 31-42.

Peter Senn, "Science as a Source of the Law", in Jürgen Backhaus The Elgar Companion to Law and Economics, Aldershot: Elgar, 1998.

Knut Wicksell, Finanztheoretische Untersuchungen, Jena: Gustav Fischer, 1896. 
